\title{
Developmental Upregulation of an Alternative Form of pcp2 with Reduced GDI Activity
}

\author{
Jaroslaw J. Barski • Brad M. Denker • Jiazhen Guan • \\ Matthias Lauth • Fabio Spreafico • Andrzej Fertala • \\ Michael Meyer
}

Published online: 5 October 2013

(C) The Author(s) 2013. This article is published with open access at Springerlink.com

\begin{abstract}
The pcp2/L7 gene is characterized by its very cell type-specific expression restricted to cerebellar Purkinje cells and retinal bipolar neurons. Although remarkable progress as to the biochemical properties of the encoded protein has been made, knowledge on its physiological functions remains sparse. While characterizing a pcp2-driven transgenic strain, we observed the presence of a longer, so far unknown, pcp2 transcript. Different from another recently discovered splice variant, ret-pcp2, expression of this novel transcript is observed in bipolar as well as cerebellar Purkinje cells of mid-postnatal mice. The protein encoded by our novel variant appears to be less efficient
\end{abstract}

Jaroslaw J. Barski and Brad M. Denker contributed equally to this work.

J. J. Barski $(\bowtie)$

Center for Experimental Medicine, Medical University of Silesia, ul.

Medyków 4, 40-752 Katowice, Poland

e-mail: jbarski@sum.edu.pl

\section{J. J. Barski}

Department of Physiology, Medical University of Silesia, 40-752 Katowice, Poland

B. M. Denker · J. Guan

Department of Medicine, Renal Division, Brigham and Women's

Hospital and Harvard Medical School, Boston, MA 02115, USA

\section{Lauth}

Institute of Molecular Biology and Tumor Research, Philipps

Universität, 35032 Marburg, Germany

F. Spreafico

Formerly Max-Planck-Institute of Neurobiology,

82152 Martinsried, Germany

\section{A. Fertala}

Department of Orthopaedic Surgery, Thomas Jefferson University, Philadelphia, PA 19107, USA

M. Meyer

Institute of Physiology, Ludwig-Maximilians University, 80336 Munich, Germany in binding to $\mathrm{G} \alpha$ subunits compared to the original $\mathrm{L} 7 / \mathrm{pcp} 2$ protein and it is also less inhibitory with respect to GTP $\gamma$ binding. Its expression in the eye appears to be independent from eye opening in postnatal mice.

Keywords pcp $2 \cdot \mathrm{L} 7 \cdot$ Splice variant $\cdot$ Cerebellum

\section{Introduction}

A remarkable feature of the pcp2/L7 gene is its cell typespecific expression. Since its discovery in 1988 [20, 21], its protein and mRNA products have been repeatedly localized exclusively to cerebellar Purkinje cells (PC) and retinal bipolar cells in various species, including mouse and human [4, 5, 15, 16, 22, 27, 28, 35].

High conservation of protein and DNA sequence, restricted expression, and the relatively late appearance of the gene products after neurogenesis [20, 21, 26, 32, 35] suggested important roles for neuronal maturation. Besides a partial resemblance to platelet-derived growth factor [21], initial sequence comparison failed to provide functional insight. Surprisingly, two different targeted null mutant mouse strains lacked functional or morphological alterations [17, 27]. More detailed studies however found, that mice null mutant for pcp2 show enhanced motor learning abilities [11]. Studies into the cell biology of pcp2 revealed an interesting dissociation of mRNA and protein localization in PC, with the former accumulating in dendrites and the latter being more equally distributed within all cellular compartments [5, 28, 34, 35]. Moreover, the potential for activity-dependent regulation of pcp2 was demonstrated [29]. Insight into function was boosted with the discovery of interaction of pcp 2 protein with $\mathrm{G} \alpha$ subunits $[12-14,18,19,22,31]$, and the recognition of other $\mathrm{G} \alpha-$ interacting proteins sharing a structural feature, the GoLOCO motif, with pcp2 [23]. While characterizing a pcp2-driven 
transgenic strain $[2,3]$, we realized the presence of a longer pcp2 transcript. Subsequently, we determined its structure, expression pattern, activity-dependent regulation, and subcellular localization as well as key biochemical properties of the encoded protein. The alternative transcript characterized here is different from another recently published product $[33,35]$.

\section{Material and methods}

C57Bl/6 mice were used for all experiments. To determine the influence of light on pcp2 expression, adult mice or mothers with their litters were kept in darkness, and then sacrificed in the dark. Controls were housed under standard light conditions (12 h light/12 h dark). All animal holding and experiments were done in accordance with the national animal welfare regulations and institutional rules.

RNA isolation was performed as described elsewhere [8]. For reverse transcription, $1 \mu \mathrm{g}$ of total RNA and $0.5 \mu \mathrm{g}$ oligo-dT primer (GIBCO BRL) were mixed in $12 \mu$ of Tris-EDTA (TE) buffer $\mathrm{pH} 7.4$ and then incubated for $5 \mathrm{~min}$ at $90{ }^{\circ} \mathrm{C}, 10 \mathrm{~min}$ at $37^{\circ} \mathrm{C}$ and $15 \mathrm{~min}$ at room temperature. Each sample was then incubated at $37{ }^{\circ} \mathrm{C}$ for $1 \mathrm{~h}$ with $4 \mu \mathrm{l} 5 \times$ first-strand buffer (GIBCO BRL), $2 \mu$ DTT ( $0.1 \mathrm{M}), 0.5 \mu \mathrm{l}$ of $0.25 \mathrm{mM}$ dNTP mix, $0.5 \mu \mathrm{l}$ RNAse inhibitor (40 U/ $\mu \mathrm{l}$, Boehringer), and $0.8 \mu \mathrm{l}$ reverse transcriptase (200 U/ $\mu$ l, SuperScript, GIBCO BRL). Afterwards, $10 \mu \mathrm{l}$ of TE buffer were added to obtain a total volume of $30 \mu \mathrm{l}$.

PCR (36 cycles) was carried out on $1 \mu \mathrm{l}$ of cDNA in a reaction mixture containing $1 \times \mathrm{PCR}$ buffer, $1.5 \mathrm{mM} \mathrm{MgCl}_{2}$, $0.4 \mu \mathrm{M}$ of each primer, and $0.625 \mathrm{U} \mathrm{Taq}$ polymerase (GIBCO BRL) according to the scheme: $5^{\prime} 95^{\circ} \mathrm{C}\left[30^{\prime \prime} 95^{\circ} \mathrm{C}, 30^{\prime \prime} 72^{\circ} \mathrm{C}\right.$, $\left.1^{\prime} 72{ }^{\circ} \mathrm{C}\right] 5^{\prime} 72^{\circ} \mathrm{C}$.

To control for sample loading, reverse transcription polymerase chain reaction (RT-PCR) for GAPDH (21 cycles) was carried out for all samples. The whole reaction mixture $(25 \mu \mathrm{l})$ was loaded on $2 \%$ agarose gels containing ethidium bromide.

Both splice variants were detected with primers: L7sense 5'AAGGCTTCTTCAACCTGCTGA-3' and L7anti 5'-GCTG TTCCTGCGGAAGCTGAG-3'. The new splice variant was specifically detected with primers: L7 sense (as above) and L73Aanti 5'-TCCCAGTACTCAAGAAACAGG-3' (Fig. 1b). GAPDH expression was detected with primers: sense $5^{\prime}$-AC CACAGTCCATGCCATCAC-3' and antisense 5'-TCCA CCACCCTGTTGCTGTA-3'.

To verify the PCR products, bands of interest were extracted from the gel, subcloned into the pCRII plasmid (TA Cloning Kit, Invitrogen) and sequenced on an ABI PRISM 377 DNA Sequencer (Perkin-Elmer). Sequence comparisons were performed using BLAST (NCBI, Bethesda, MD, USA).

Molecular modeling was performed using the SYBYL software, version 7.2 (Tripos Inc.). The model was generated, in part, by homology modeling with filamentous hemagglutinin secretion domain (Protein Data Bank, ID code 1rwr) as a template. The model was energy-minimized using a conjugate gradient method and subjected to repeating cycles of molecular dynamics using Kollman force fields and united atoms [30].

In situ hybridization for detection of the novel transcript was carried out at $38{ }^{\circ} \mathrm{C}$ according to a protocol described elsewhere [24]. The oligonucleotide DNA probe was complementary to base pairs $2,461-2,507$ of the pcp2 genomic sequence (Fig. 1a; accession number S40022) [25]. The hybridization specificity was checked by competing with $100 \times$ excess of the cold probe.

As described later (see "Results" section), the novel longer transcript encodes a shorter protein variant than the known shorter transcript. We refer to the native proteins as long pcp2 and short pcp2 proteins, respectively.

For the generation of recombinant glutathione S-transferase (GST)-pcp2 fusion proteins, cDNAs corresponding to short and longer transcript were cloned into the EcoRI and XhoI sites of the pGEX-4T-1 vector (GE Healthcare) in frame with the glutathione-S-transferase/thrombin cleavage site. A single direct primer (L7Eco.d: AGG GCG AAT TCA TGG AGG AGC AGC GCT GTT C), containing an EcoRI site, was used to amplify both forms of pcp2 from mouse cerebellar cDNA. As reverse primers, both containing an XhoI restriction site, L7lgXho.r ( TAG GAT CTC GAG AAC TCT CAA GGA GCT TGT G) provided specificity for the short transcript, while L7shXho.r (AAC AGG CTC GAG GAT TAT TTT GAG TTC AAA GC) amplified the long transcript only.

The resulting plasmids (GLL7 for the long form and GSL7 for the short form) were transformed into the JM109 Escherichia coli to yield recombinant proteins (we refer to the GST-short pcp2 protein as SL7 and to the GST-long pcp2 protein as L7) as was the empty pGEX vector for the production of GST alone as a control. Proteins were obtained after $1 \mathrm{mM}$ IPTG induction and purified by sepharose-glutathione affinity chromatography. Purity and integrity of the recombinant fusion proteins were verified by sodium dodecyl sulfatepolyacrylamide gel electrophoresis (SDS-PAGE; not shown).

Recombinant baculovirus expressed purified $\mathrm{G} \alpha \mathrm{o}$ and $\mathrm{G} \alpha \mathrm{il}$ [10] were kindly provided by Steve Graber (Morgantown West, VA, USA $)$ and were preincubated at 1:1 $\mathrm{M}$ ratio $(2.5 \mathrm{pmol})$ with purified noncleaved GST fusion proteins for AGS3 (cDNA provided by Steve Lanier, New Orleans, LA, USA), long pcp2, short pcp2, and GST alone in buffer A (20 mM HEPES, pH 8.0, $130 \mathrm{mM} \mathrm{NaCl}, 3 \mathrm{mM} \mathrm{MgCl}_{2}, 1 \mathrm{mM}$ DTT, 1 mM EDTA, $10 \mu \mathrm{g} /$ $\mu \mathrm{l}$, bovine serum albumin, and $0.1 \%$ Triton X-100) for $20 \mathrm{~min}$ at $25^{\circ} \mathrm{C}$ in the presence of $1 \mu \mathrm{M}$ GDP. At $t=0$, GTP $\gamma \mathrm{S}^{35}(1 \mu \mathrm{M}$; specific activity, $1 \times 10^{5} \mathrm{cpm} / \mathrm{pmol}$, New England Nuclear) was added for $60 \mathrm{~min}$. Reactions were terminated by dilution into icecold phosphate-buffered saline (PBS) and rapidly filtered through $25 \mathrm{~mm}$ round nitrocellulose membranes (Millipore, Billerica, MA, USA; $0.45 \mu \mathrm{M} \mathrm{HA}$ ), washed twice with $20 \mathrm{ml}$ of cold PBS. Filters were placed in scintillation fluid and counted 

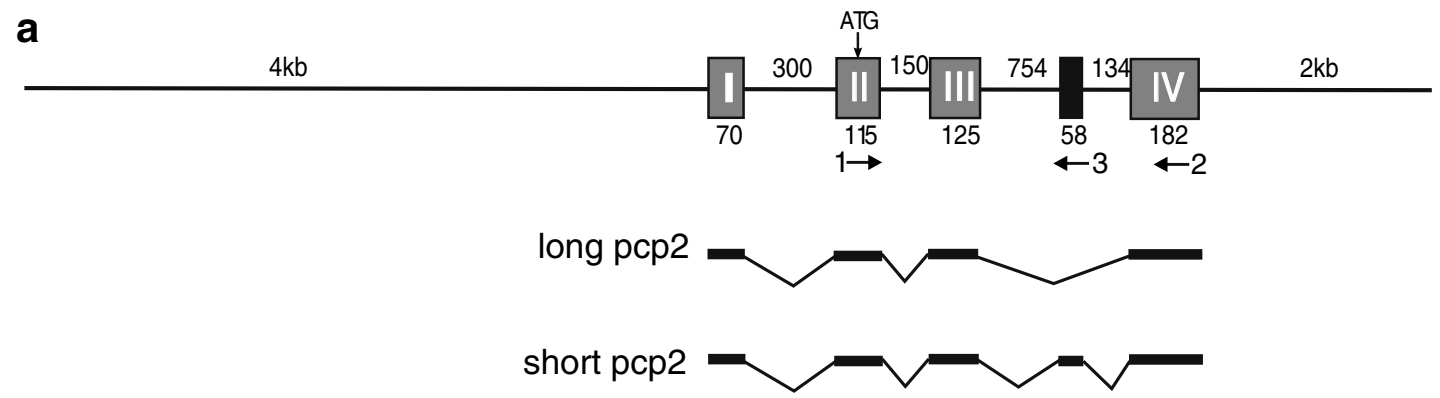

b

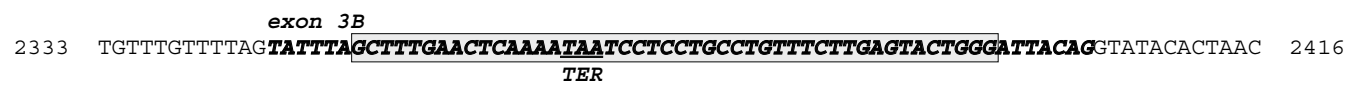

\section{C}

long pcp2

MEEQRCSLQAGPGQNPESQGGPAPEMDNLMDMLVNTQGRRMDDQAVTVDSLPGFQPIGPYDGMQKRPGTLSPQPLLTPQDPAALSFRRNSSPQPQTQAP

short pcp2

MEEQRCSLQAGPGQNPESQGGPAPEMDNLMDMLVNTQGRRMDDQRVTVDSLPGFQPIGPKYLALNSK

d

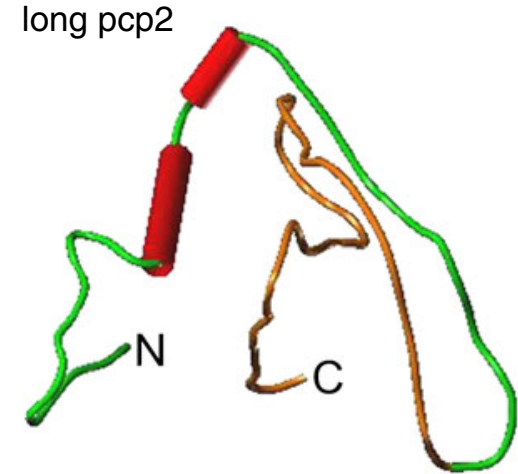

Fig. 1 Structure and sequence of the novel pcp2 transcript and protein. a Structure of the transcripts for long and short pcp2 (long and short refer to the protein and not to the mRNA). Gray and black boxes indicate previously known exons and the novel exon $3 \mathrm{~B}$, respectively. Lengths of exons and introns are indicated in base pairs. Arrows indicate primers used for RT-PCR. 1 L7sense, 2 L7anti, 3 L73Aanti. b Nucleotide sequence of exon 3B (bold italic) with intronic junctions. TER indicates the in-frame translation stop codon, and the gray-shaded box is the

in a Packard Tri-Carb A2200 liquid scintillation counter. Blank filters (no protein) were used to determine background and nonspecific binding was determined with parallel filters incubated with excess $(0.1 \mathrm{mM})$ cold GTP $\gamma \mathrm{S}$ (Sigma).

In vitro translated $\mathrm{G} \alpha$ subunits were $\left[\mathrm{S}^{35}\right]$-methionine labeled and prepared as previously described using the TNT coupled in vitro translation system (Promega) [9]. Similar amounts of translate $(5-10 \mu \mathrm{l})$ were incubated with $0.3 \mu \mathrm{g}$ of GST, AGS3, long pcp2, or short pcp2 for $2 \mathrm{~h}$ at room temperature in buffer A $+0.1 \%$ Triton X-100, $150 \mathrm{mM} \mathrm{NaCl}$, and $20 \mu \mathrm{M}$ GDP (binding buffer). Glutathione agarose beads were added for

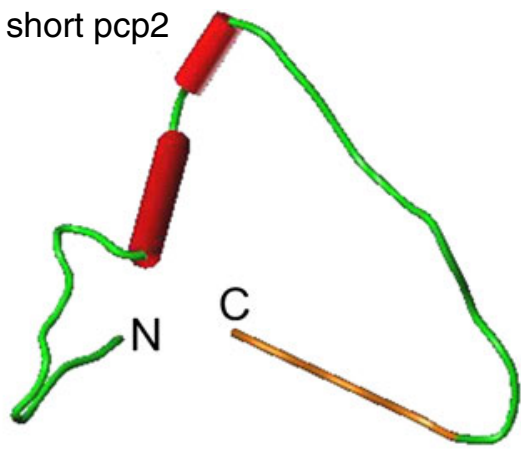

complement of the in situ hybridization probe. c Sequence of short and long pcp2 proteins. The gray-shaded box represents the GoLOCO motif. Sequences unique to either protein are framed, and predicted C-terminal phosphorylation sites are underlined with the phosphorylated serine being indicated by an upward arrow. d Computer-generated models of long and short pcp2. C-terminal domains that distinguish the two variants are indicated in orange. Red cylinders represent $\alpha$-helical structures of the GoLOCO domain

$30 \mathrm{~min}$ at room temperature, centrifuged, and washed three times with $1 \mathrm{ml}$ ice-cold binding buffer. Samples were eluted in $2 \times$ SDS-PAGE sample buffer by heating at $100{ }^{\circ} \mathrm{C}$ for $5 \mathrm{~min}$ and analyzed by SDS-PAGE and autoradiography.

\section{Results}

RT-PCR on eye and cerebellar RNA using primers placed in exon 2 (L7sense) and 4 (L7anti) (Fig. 1b), consistently detected a novel 350 bp product together with the $300 \mathrm{bp}$ band expected 
Fig. 2 Developmental expression of the novel pcp2 transcript. Transcripts encoding short pcp2 protein were detected by transcript-specific RT-PCR at the indicated postnatal time points (upper panel)

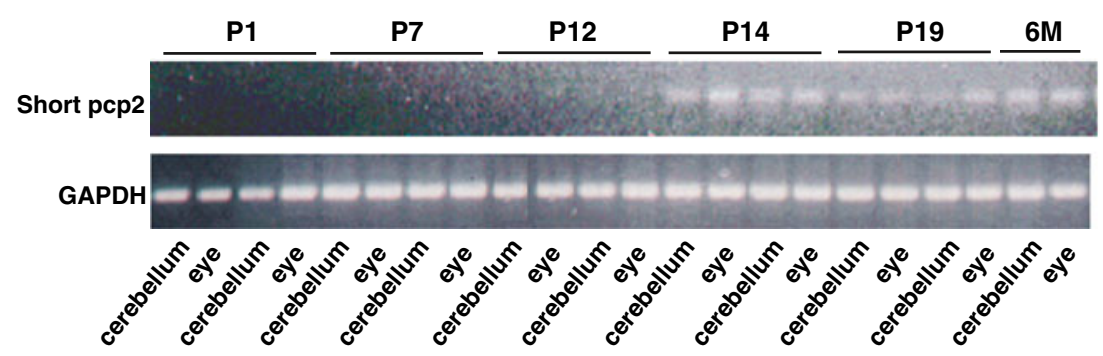

from the known pcp2 gene structure (Fig. 2). Sequencing and analysis of the RT-PCR product revealed a novel stretch of $58 \mathrm{bp}$ between 2,455 and 2,513 bp within intron 3 (Fig. 1a). This analysis also revealed splice donor and acceptor sites flanking this exon. The novel exon, dubbed 3B, can be included or excluded resulting in two different pcp2 transcripts (Fig. 1b). In the following, we will refer to the originally published exon 3 as exon 3A. Interestingly, when included, exon 3B introduces an in frame stop codon. Thus, exon 4 does not contribute to the coding of this alternative product. As the translated product is 32 amino acids shorter than the originally published protein (here referred to as long pcp2 protein), we call it short pcp2 protein. The GoLOCO motif of long pcp2 is found between amino acids 27 and 45 , and is entirely encoded by exon $3 \mathrm{~A}$. It is, therefore, not altered in short pcp2. The C-terminal, exon 4-encoded part of pcp2 contains a cluster of predicted phosphorylation sites (scores higher than 0.95; NetPhos 2.0, CBS Technical University of Denmark) [6]. These are a putative PKC site at serine 85 (PAALSFRNN), a CaM kinase II/PKA site around serine 90
(FRRNSSPQP), and a Cam kinase II/PKA/PKG site around serine 91 (Fig. 1c). Two of them are conserved between mouse, rat, and human [35]. With the exception of another predicted site at serine 18 (QNPSESQGGP), none of the putative phosphorylation sites of long pcp2 is present in the short pcp2.

Computer analysis of long and short pcp2 protein variants did not reveal many characteristic structural motives. Except for $\alpha$-helical domains corresponding to the GoLOCO motif, the proteins are essentially characterized by an extended structure (Fig. 1d).

To study expression of the novel transcript, we designed a primer placed in the novel exon 3B (L73Aanti; Fig. 1b). RT-PCR using primers L7sense and L73Aanti confirmed the presence of the novel transcript in eye and cerebellum of adult mice (Fig. 2). During development, expression of the novel form is first detected between P12 and P14 in eye and cerebellum. The presence of the long form was observed already at P7 (data not shown).

To localize the novel transcript at the cellular level, in situ hybridization was performed on cerebellar and retinal sections

Fig. 3 Localization of transcripts coding for the novel short pcp2 protein by in situ hybridization in adult C57BL/6 mice. a Dark field imaging of the cerebellar. $g$ Granular cell layer, $p$ Purkinje cell layer, $m$ molecular layer. Bar $100 \mu \mathrm{m}$. b Control section. Bar $100 \mu \mathrm{m}$. c Bright field picture of Purkinje cells showing silver grains over cell bodies of Purkinje cells (arrow heads). Bar $100 \mu \mathrm{m}$. d Phase contrast image of mouse retinal layers. $P E$ pigment epithelium, $R \& C$ rod and cone photoreceptors, $O N L$ outer nuclear layer, $O P L$ outer plexiform layer, $I N L$ inner nuclear layer, $I P L$ inner plexiform layer, $G C L$ ganglion cell layer. Bar $100 \mu \mathrm{m}$. e Dark field image of a hybridized retina section. Bar $100 \mu \mathrm{m}$. f Control section. Bar $100 \mu \mathrm{m}$
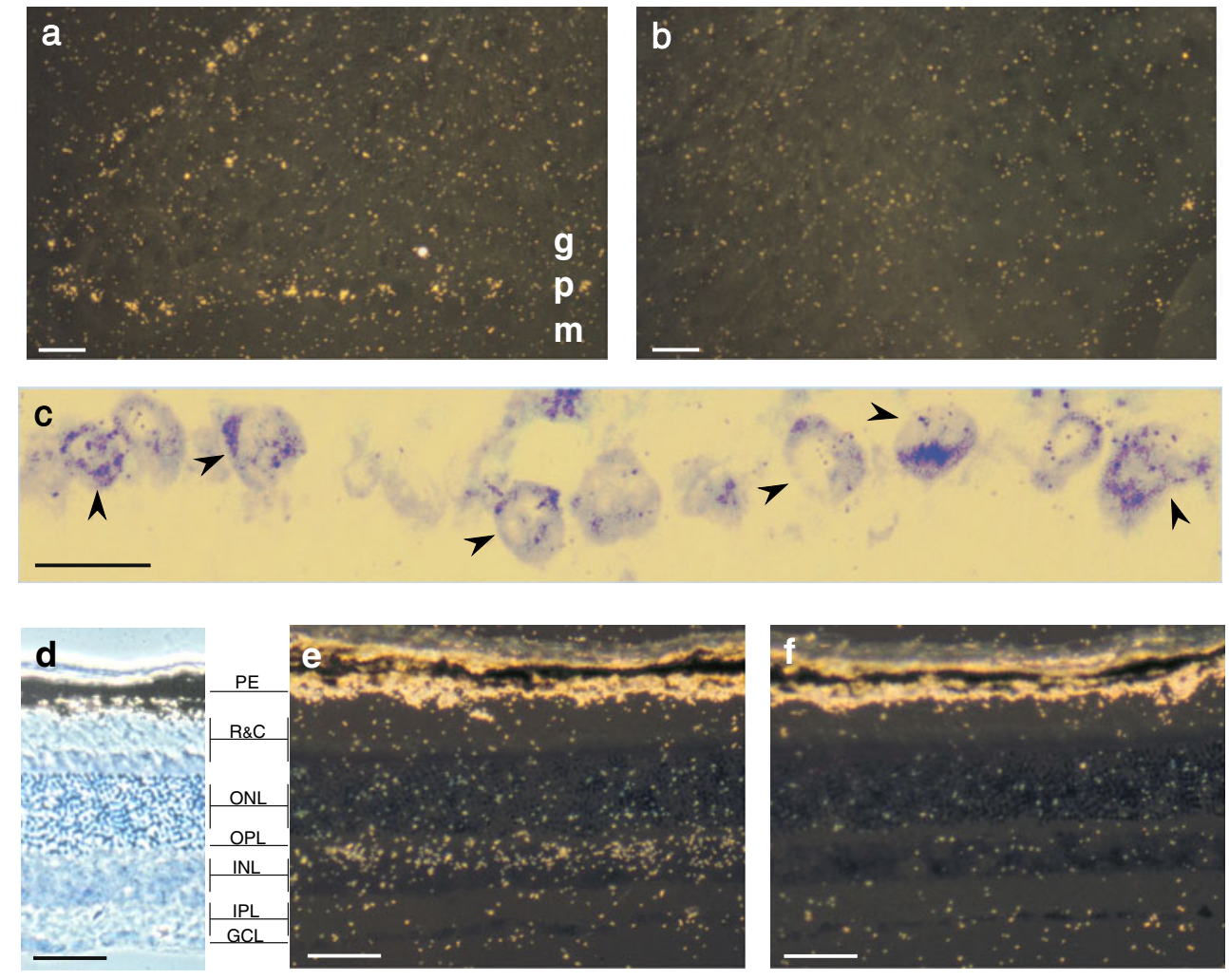
using an oligonucleotide probe corresponding to $46 \mathrm{bp}$ of exon 3B. Microscopic analysis revealed specific signals within the cerebellar cortex at the level of the PC layer (Fig. 3a, b). Higher magnification microscopy revealed the presence of silver grains over the cell bodies of PC (Fig. 3c). In sections of the retina, labeling was detected in the outer part of inner nuclear layer, where bipolar neurons are localized (Fig. 3d, e). Specific signal was also found at the outer plexiform layer.

Because expression of transcripts encoding the novel short pcp2 protein was first detected around the time of eye opening in mice (P12-14) [25], we wondered whether it would be modulated by maintenance of mice in the dark (Fig. 4). Pcp2 expression was analyzed in adult animals housed in the dark for $60 \mathrm{~h}$ or 6 days, respectively, and compared to animals kept under standard light-dark conditions (Fig. 4a). After the indicated time, animals were sacrificed in the dark, and tissue samples were immediately dissected for analysis. RT-PCR using the exon 2-exon 4 primer pair detected the presence of both transcripts in the eye and the cerebellum. It failed, however, to reveal any differences between groups. To investigate a possible induction of expression by light at the time of eye opening, P1 litters were maintained in the dark together with their mothers (Fig 4b). Pups were sacrificed in the dark at P15 and P19, tissues dissected and RT-PCR performed as above. Controls were pups kept under standard light-dark conditions. Again, both splice variants were detected in both tissues at levels apparently not influenced by dark rearing.
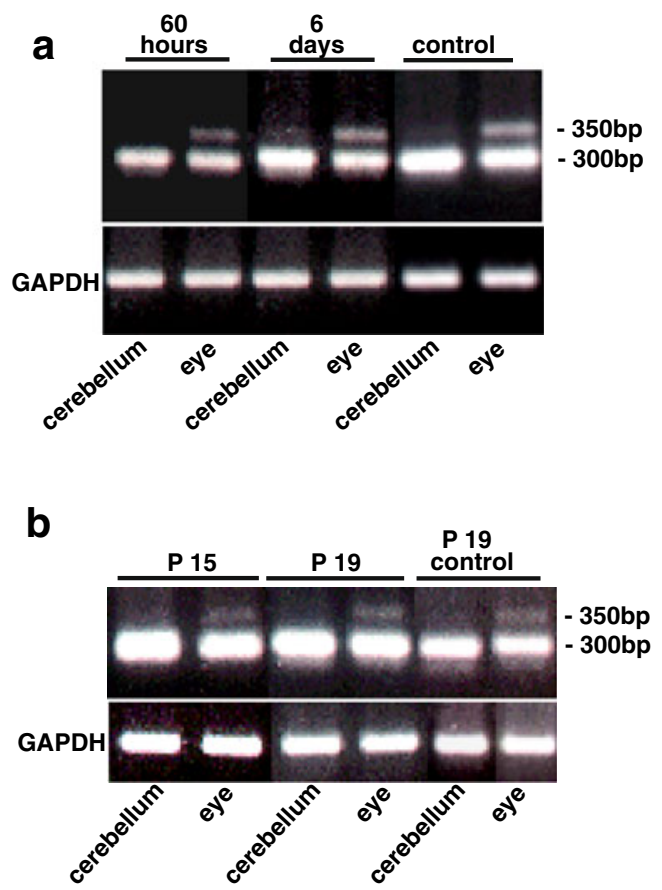

Fig. 4 Influence of dark breeding on expression of pcp2. a Adult C57B1/6 mice were kept in darkness for $60 \mathrm{~h}$ or 6 days after which tissues were processed for RT-PCR common for both transcripts. b P1 pups were kept in darkness with their mothers until tissue dissection at P15 and P19. Controls were kept under standard light conditions. The length of the amplimers is given in base pairs
To investigate whether short pcp2 protein functions as a GDI for $G \alpha$ subunits, we first examined whether short pcp2 interacts with $\mathrm{G} \alpha$ subunits. Figure 5a shows in vitro translated and $\left[\mathrm{S}^{35}\right]$-methionine labeled $\mathrm{G} \alpha_{0}, \mathrm{G} \alpha \mathrm{il}, 2$, and 3 used in GST pull-down experiments with GST (negative control), AGS (positive control), long pcp2 (L7), and short pcp2 (SL7). The GST proteins are shown in the Coomassie-stained gel below and the amount of labeled $\mathrm{G} \alpha$ subunit precipitating under each condition is shown in the autoradiogram. The relative interaction of SL7 and L7 with G $\alpha \mathrm{il}, \mathrm{G} \alpha \mathrm{i}-2, \mathrm{G} \alpha \mathrm{i}-3$, and $\mathrm{G} \alpha \mathrm{o}$ is summarized in the bar graphs (Fig. 5b) relative to the AGS3 binding for this experiment. The experiment was repeated twice with similar results. It appears that for all four tested $\mathrm{G} \alpha$ subunits, the preferential binding was AGS $>>$ long pcp $2>$ short pcp2. Albeit, binding of SL7 was weak when compared to AGS3 it was higher than binding of GST alone. Importantly, binding of SL7 was clearly less than that of LL7. As expected from other reports [18], binding to $\mathrm{G} \alpha$ o was weak for all three GST fusion proteins in comparison with the G $\alpha$ i family. There did not appear to be any preference for short pcp2 in comparison with long pcp2 for interacting with $G \alpha o$ or any of the $G \alpha i$ subunits.

We next examined the GDI potency of short pcp2 protein in comparison with long pcp2 and AGS3 (Fig. 5c). Baculovirus-purified $G \alpha o$ and $G \alpha i 1$ were used for these experiments and GTP $\gamma S^{[35]}$ binding to each $\mathrm{G} \alpha$ subunit was compared in the presence and absence of GST (negative control and binding set to $100 \%$ ), GST-pcp2 long (L7), GST-pcp2 short (SL7), and GST-AGS3 under conditions very similar to those previously used to characterize differences between pcp2 and AGS proteins (e.g., [7]). The degree of GTP $\gamma S^{[35]}$ inhibition in these conditions mirrored the binding results shown in Fig. 5a, b. There was a small but consistent inhibition of GTP $\gamma \mathrm{S}^{[35]}$ binding to purified G $\alpha$ o (Fig. 5c) and there was no significant difference in inhibition for AGS3, short or long pcp2. However, the inhibition of GTP $\gamma \mathrm{S}^{[35]}$ binding to $\mathrm{G} \alpha \mathrm{i} 1$ revealed relative potencies indicated already by the binding experiments; AGS3>long pcp2>short pcp2. There was no significant difference in inhibition of GTP $\gamma S^{[35]}$ binding to G $\alpha$ i1 for short or long pcp2, but short pcp2 protein was significantly different from control and AGS3. Taken together, the GST pulldowns and GTP $\gamma \mathrm{S}^{[35]}$ binding results are consistent with short pcp 2 binding less avidly to G $\alpha i 1$ and therefore being a slightly less effective GDI than long pcp2.

\section{Discussion}

Our study describes alternative splicing of the pcp2/L7 gene. The protein product encoded by the novel long transcript (short pcp2 protein) lacks most of the carboxy-terminal half of the originally described protein (long pcp2 protein), but still contains the N-terminal GPR motif. It is different from the 
a

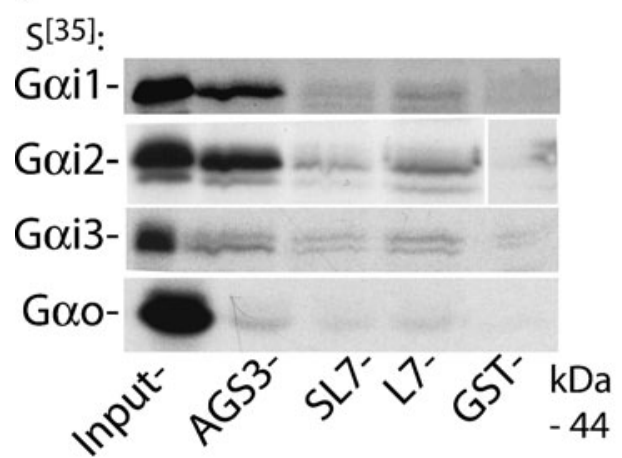

Coomassie:

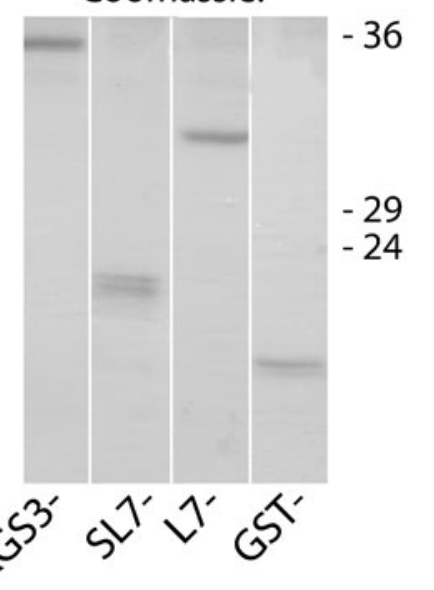

Fig. 5 Interaction with $\mathrm{G}$ protein $\alpha$-subunits. a Interaction of $\mathrm{G} \alpha \mathrm{Sub}$ units with short and long pcp 2 protein. The indicated in vitro translated and $\mathrm{S}^{35}$-methionine labeled $\mathrm{G} \alpha$ subunits were incubated with recombinant GST fusions of AGS3, and short (SL7) and long pcp2 (L7), and GST alone, and then precipitates were analyzed by SDS-PAGE (see "Material and Methods" for details). Top panel the left lane is $5 \%$ (G $\alpha \mathrm{i} 2, \mathrm{G} \alpha \mathrm{i} 3)$ or $10 \%\left(\mathrm{G} \alpha_{0}, \mathrm{G} \alpha \mathrm{i} 1\right)$ of input into the binding. Precipitated $\mathrm{G} \alpha$ subunits with each of the GST fusion proteins are shown in the subsequent lanes. The bottom panel shows Coomassie blue stained gel of the fusion proteins used in the binding experiments. Exposures are 24-48 h. b The binding of each G $\alpha$ subunit to L7 and SL7 is shown relative to the AGS3 binding. c GTP binding to baculovirus-purified G $\alpha_{0}$ (top) and

product of a recently described alternative splicing of $5^{\prime}$ exons [35]. Several additional features distinguish long from short pcp2 protein. First, there seem to be differences as to the developmental time course of expression. The novel transcripts appear to occur later although more detailed expression analysis is needed to exclude misleading effects of its low expression level. Our data on short pcp2 together with previous work [35] suggest that, at least in the cerebellum, both forms co-exist in the same cell. Its expression in retina and cerebellum distinguishes our transcript from a previously described splice variant, coined ret-pcp2, which is exclusively expressed in retinal bipolar cells and accelerates light responses [33]. Thus, generation of our short form could be readily explained by assuming that the alternative form depends on maturation of the splicing apparatus and is cell autonomous, or is induced by extrinsic systemic
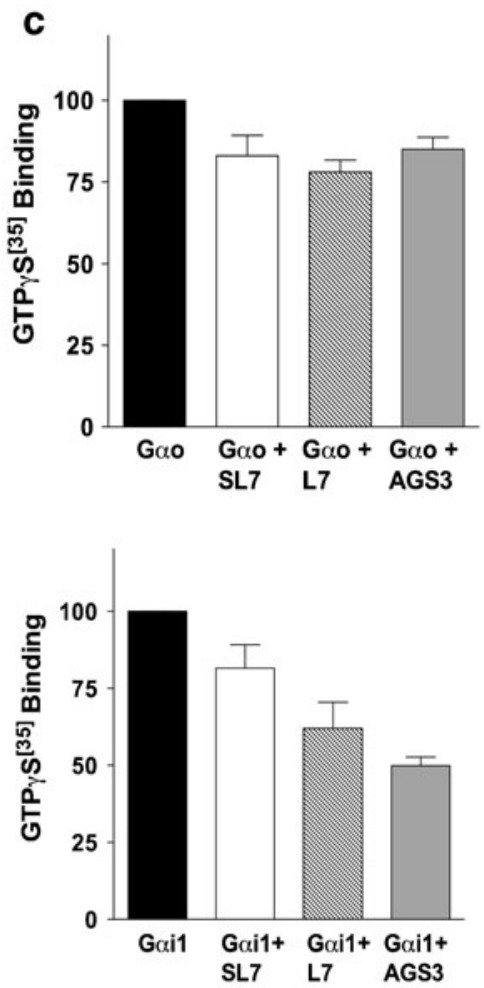

G $\alpha$ il (bottom) in absence or presence of recombinant GST fusions of AGS3, short pcp2 (SL7), and long pcp2 (L7) (see "Material and Methods" for details). Specific binding of GTP $\gamma \mathrm{S}$ to $\mathrm{G} \alpha$ subunits was determined in triplicate and set to $100 \%$. Results are the mean values \pm SEM (G $\alpha_{0}, n=8 ; \mathrm{G} \alpha \mathrm{i} 1, n=6$ independent experiments). In comparison to $\mathrm{G} \alpha \mathrm{o}$ alone, all three fusion proteins had small but significant reductions in GTP $\gamma \mathrm{S}$ binding (SL7, $p=0.017$; L7 and AGS3, $p<0.001$ ). For $\mathrm{G} \alpha \mathrm{i} 1, p=0.036$ for SL7 and $p<0.001$ for L 7 and AGS3. The differences between short and long pcp2, and long pcp2 and AGS3 did not reach statistical significance, but short pcp2 was significantly different from $\operatorname{AGS} 3(p=0.003)$

factors, e.g., hormones. It is of interest in this context, that expression of the transcripts encoding long pcp2 protein is transcriptionally activated by thyroid hormone during the second and third week of cerebellar development in the rat [1]. Earlier transcriptional activation by thyroid hormone appears to be repressed by a DNA-binding protein. Similar mechanisms, e.g., blockade of cis-acting splicing enhancers, could explain the developmental pattern of alternative splicing observed here. In contrast, use-dependent activity in the retina as initiated by eye opening is not a major factor regulating this process.

Second, biochemical properties of short and long form differ. When recombinant $\mathrm{G} \alpha$ subunits are used, both forms act as GDI, with long pcp2 protein being more potent. The meaning of increased amounts of a weaker GDI during development is unclear at present. Short pcp2 might replace long forms at some, 
but not all, specific intracellular sites. Transfection experiments so far failed to reveal such specific intracellular targeting (data not shown). This might be due to masking caused by overexpression of the protein. Alternatively, the upregulation of the short form might tune the interaction of the long form in homo- or heteromeric molecular complexes. Our data indicate that relative expression of short to long variant is stronger in retina than cerebellum. This might suggest that retinal bipolar cells, which are known to express an additional specific pcp2 isoform [33], might be particularly dependent on fine tuning of pcp2 and G-protein function. It is interesting to speculate on the differing potencies of GDI activity of long and short pcp2. Both proteins contain a single GoLOCO motif, so the differences are likely to result from important other conformational or structural differences between the isoforms. Further differentiation in the biochemical properties of the short variant might depend on the use of the alternative exon 1B, which would introduce a second GoLOCO motif [35]. We cannot exclude that functional differences between both forms are stronger when additional $\mathrm{G} \alpha$ subunits are tested. In addition, there are intriguing differences in putative post-translational modifications of short and long pcp2.

A cluster of phosphorylation sites predicted in the Cterminus of long pcp 2 is lost in the short variant. This includes a site for phosphorylation by protein kinase $\mathrm{G}$, which is abundantly expressed in PC, and possibly also in retinal bipolar cells. Further experimentation has to be awaited to see whether pcp2 is indeed a substrate for $G$ kinase, and subsequently, how hyperphosphorylation would interfere with the developmental function of pcp2.

As indicated by the work on ret-pcp2 [33], pcp2 splice variants subserve delicate and important biological roles. These might depend on the proportion of the different splice forms and their products. Future progress in understanding the biological function of pcp2 will require a careful comprehensive analysis of the expression of all its different splice variants.

\begin{abstract}
Acknowledgments We are grateful to Steve Graber and Steve Lanier for provision of materials and B. Kunkel and A. Steinberg for excellent technical assistance. Many thanks to Hans Thoenen, Y-A Barde, and to our colleagues at the Institute of Ophthalmology, University College London.
\end{abstract}

Conflict of Interest The authors declare that the research was conducted in the absence of any commercial or financial relationships that could be construed as a potential conflict of interest.

Open Access This article is distributed under the terms of the Creative Commons Attribution License which permits any use, distribution, and reproduction in any medium, provided the original author(s) and the source are credited.

\section{References}

1. Anderson GW, Larson RJ, Oas DR, Sandhofer CR, Schwartz HL, Mariash $\mathrm{CN}$, et al. Chicken ovalbumin upstream promoter-transcription factor (COUP-TF) modulates expression of the Purkinje cell protein-2 gene. A potential role for COUP-TF in repressing premature thyroid hormone action in the developing brain. J Biol Chem. 1998;273: 16391-9.

2. Barski JJ, Dethleffsen K, Meyer M. Cre recombinase expression in cerebellar Purkinje cells. Genesis. 2000;28:93-8.

3. Barski JJ, Lauth M, Meyer M. Genetic targeting of cerebellar Purkinje cells: history, current status and novel strategies. Cerebellum. 2002;1:111-8.

4. Berrebi AS, Oberdick J, Sangameswaran L, Christakos S, Morgan JI, Mugnaini E. Cerebellar Purkinje cell markers are expressed in retinal bipolar neurons. J Comp Neurol. 1991;308:630-49.

5. Bian F, Chu T, Schilling K, Oberdick J. Differential mRNA transport and the regulation of protein synthesis: selective sensitivity of Purkinje cell dendritic mRNAs to translational inhibition. Mol Cell Neurosci. 1996; 7:116-33.

6. Blom N, Gammeltoft S, Brunak S. Sequence and structure-based prediction of eukaryotic protein phosphorylation sites. J Mol Biol. 1999;294:1351-62.

7. Cao X, Cismowski MJ, Sato M, Blumer JB, Lanier SM. Identification and characterization of AGS4: a protein containing three G-protein-regulatory motifs that regulate the activation state of Gialpha. J Biol Chem. 2004;279:27567-74.

8. Chomczyński P, Sacchi N. Single-step method of RNA isolation by acid guanidinium thiocyanate-phenol-chloroform extraction. Anal Biochem. 1987;162:156-9.

9. Denker BM, Boutin PM, Neer EJ. Interactions between the aminoand carboxyl-terminal regions of G.alpha subunits: analysis of mutated G.alpha.o/G.alpha.i2 chimeras. Biochemistry. 1995;34:5544-53.

10. Graber SG, Figler RA, Garrison JC. Expression and purification of functional $\mathrm{G}$ protein alpha subunits using a baculovirus expression system. J Biol Chem. 1992;267:1271-8.

11. Iscru E, Serinagaoglu Y, Schilling K, Tian J, Bowers-Kidder SL, Zhang R, et al. Sensorimotor enhancement in mouse mutants lacking the Purkinje cell-specific Gi/o modulator, Pcp2(L7). Mol Cell Neurosci. 2009;40:62-75.

12. Kimple R, Kimple M, Betts L, Sondek J, Siderovski D. Structural determinants for GoLoco-induced inhibition of nucleotide release by Galpha subunits. Nature. 2002;416:878-81.

13. Kinoshita-Kawada M, Oberdick J, Xi ZM. A Purkinje cell specific GoLoco domain protein, L7/Pcp-2, modulates receptor-mediated inhibition of Cav2.1 $\mathrm{Ca} 2+$ channels in a dose-dependent manner. Brain Res Mol. 2004;132:73-86.

14. Luo Y, Denker BM. Interaction of heterotrimeric $\mathrm{G}$ protein galphao with purkinje cell protein-2. Evidence for a novel nucleotide exchange factor. J Biol Chem. 1999;274:10685-8.

15. Martin PR, Grunert U. Spatial density and immunoreactivity of bipolar cells in the macaque monkey retina. J Comp Neurol. 1992;23:269-87.

16. Mochizuki N, Cho G, Wen B, Insel PA. Identification and cDNA cloning of a novel human mosaic protein, LGN, based on interaction with G[alpha]i2. Gene. 1996;181:39-43.

17. Mohn AR, Feddersen RM, Nguyen MS, Koller BH. Phenotypic analysis of mice lacking the highly abundant Purkinje cell- and bipolar neuron-specific PCP2 protein. Mol Cell Neurosci. 1997;9:63-76.

18. Natochin M, Gasimov KG, Artemyev NO. Inhibition of GDP/GTP exchange on $\mathrm{G}$ alpha subunits by proteins containing G-protein regulatory motifs. Biochemistry. 2001;40:5322-8.

19. Natochin M, Gasimov KG, Artemyev NO. A GPR-protein interaction surface of Gi(alpha): implications for the mechanism of GDPrelease inhibition. Biochemistry. 2002;41:258-65. 
20. Nordquist DT, Kozak CA, Orr HT. cDNA cloning and characterization of three genes uniquely expressed in cerebellum by Purkinje neurons. J Neurosci. 1988;8:4780-9.

21. Oberdick J, Levinthal F, Levinthal C. A Purkinje cell differentiation marker shows a partial DNA sequence homology to the cellular sis/ PDGF2 gene. Neuron. 1988;1:367-76.

22. Redd KJ, Oberdick J, McCoy J, Denker BM, Luo Y. Association and colocalization of $\mathrm{G}$ protein alpha subunits and Purkinje cell protein 2 (Pcp2) in mammalian cerebellum. J Neurosci Res. 2002;70:631-7.

23. Siderovski DP, Diverse-Pierluissi M, De Vries L. The GoLoco motif: a Galphai/o binding motif and potential guanine-nucleotide exchange factor. Trends Biochem Sci. 1999;24:340-1.

24. Spreafico F, Barski JJ, Farina C, Meyer M. Mouse DREAM/ Calsenilin/KChIP3: gene structure, coding potential, and expression. Mol Cell Neurosci. 2001;17:1-16.

25. Theiler K. The house mouse. Development and normal stages from fertilization to 4 weeks of age. Berlin: Springer; 1972.

26. Vandaele S, Nordquist DT, Feddersen RM, Tretjakoff I, Peterson AC, Orr HT. Purkinje cell protein-2 regulatory regions and transgene expression in cerebellar compartments. Genes Dev. 1991;5:1136-48.

27. Vassileva G, Smeyne RJ, Morgan JI. Absence of neuroanatomical and behavioral deficits in L7/pcp-2-null mice. Brain Res Mol Brain Res. 1997;46:333-7.

28. Wanner I, Baader SL, Brich M, Oberdick J, Schilling K. Subcellular localization of specific mRNAs and their protein products in Purkinje cells by combined fluorescence in situ hybridization and immunocytochemistry. Histochem Cell Biol. 1997;108:345-57.
29. Wanner I, Baader SL, Oberdick J, Schilling K. Changing subcellular distribution and activity-dependent utilization of a dendritically localized mRNA in developing Purkinje cells. Mol Cell Neurosci. 2000;15:275-87.

30. Weiner SJ, Kollman PA, Case DA, Singh UC, Ghio C, Alagona $\mathrm{G}$, et al. A new force field for molecular mechanical simulation of nucleic acids and proteins. J Am Chem Soc. 1984;106:76584.

31. Willard FS, McCudden CR, Siderovski DP. G-protein alpha subunit interaction and guanine nucleotide dissociation inhibitor activity of the dual GoLoco motif protein PCP-2 (Purkinje cell protein-2). Cell Signal. 2006;18:1226-34.

32. Wu Y, Cutting GR. Developmentally regulated expression of GABA receptor rho1 and rho2 subunits, L7 and cone-rod homeobox (CRX) genes in mouse retina. Brain Res. 2001;912:1-8.

33. Xu Y, Sulaiman P, Feddersen RM, Liu J, Smith RG, Vardi N. Retinal ON bipolar cells express a new PCP2 splice variant that accelerates the light response. J Neurosci. 2000;28:8873-84.

34. Zhang R, Zhang X, Bian F, Pu XA, Schilling K, Oberdick J. 3'UTRdependent localization of a Purkinje cell messenger RNA in dendrites. Cerebellum. 2008;7:482-93.

35. Zhang X, Zhang H, Oberdick J. Conservation of the developmentally regulated dendritic localization of a Purkinje cell-specific mRNA that encodes a G-protein modulator: comparison of rodent and human Pcp2(L7) gene structure and expression. Brain Res Mol Brain Res. 2002;105:1-10. 